\title{
Incorporation of Whole Lupin, Lupinus albus, Seed Meal in Commercial Extruded Diets for Rainbow Trout, Oncorhynchus mykiss: Effect on Growth Performance, Nutrient Digestibility, and Muscle Fatty Acid Composition
}

\author{
Aliro S. Bórquez, Adrián J. Hernández ${ }^{1}$, and Patricio Dantagnan \\ Grupo de Nutrición Acuícola, Núcleo de Producción Alimentaria/Escuela de Acuicultura, \\ Facultad de Recursos Naturales, Universidad Católica de Teтисо, PO Box 15-D, Teтuco, \\ Chile
}

PATricio SAEZ

Fish Nutrition Research Laboratory, Department of Animal and Poultry Science, University of Guelph, Guelph, Canada

EDISON SERRANo

Department of Animal and Aquaculture Sciences, Aquaculture Protein Centre, CoE/Norwegian University of Life Sciences, PO Box 5003, 1432 Ås, Norway

\begin{abstract}
Whole lupin seed meal was evaluated as partial replacement for fishmeal in extruded diets for rainbow trout, with particular emphasis on the effect on growth performance and apparent digestibility coefficient (ADC) of protein, lipids, carbohydrates, and energy. Effect on muscle fatty acid composition was also evaluated. All diets were formulated to be isonitrogenous and isoenergetic and to contain approximately $45 \%$ crude protein and $5.5 \mathrm{kcal}$ energy g/diet. Diets were formulated to include whole lupin seed meal at $0,10,15$, and $20 \%$. Triplicate groups of fish weighing $65.9 \pm$ $15.1 \mathrm{~g}$ on average were fed twice a day until apparent satiation during $12 \mathrm{wk}$. Growth, feed intake, hepatosomatic index, hepatic histology, proximate composition of whole body, and muscular fatty acid profile were determined. Growth and feed utilization were similar in all treatments and whole-body composition did not vary among treatments. Polyunsaturated fatty acids of the n-6 and n-3 series remained constant in muscle as the amount of lupin in diets increased. Furthermore, the ADCs were similar among all diets. These results suggest that inclusion of whole lupin seed meal up to $20 \%$ in extruded diets for rainbow trout do not have any negative effect on growth, feed performance, or flesh quality.
\end{abstract}

The accelerated growth of aquaculture has resulted in a high demand and use of marine protein sources for the formulation of feeds. Feed represents an important percentage of the operational costs in any intensive aquaculture process (Wurmann 2007). This elevated cost is mainly attributed to the use of fishmeal as the major protein source ingredient in the formulation of commercial feeds for most carnivorous aquatic species (Hardy and

\footnotetext{
${ }^{1}$ Corresponding author.
}

Barrows 2002). Currently, aquaculture uses an important proportion of the fishmeal world supply. In 2006, the aquaculture sector consumed about 3.06 million tonnes or $56.0 \%$ of world fishmeal production and 0.78 million tonnes or $87.0 \%$ of total fish oil production (Tacon and Nates 2007). Global availability of fishmeal has reached static production levels and the price has risen considerably (Barlow 2000; Davenport et al. 2003; FAO 2008). According to the projections, the demand for fishmeal in the coming years will increase significantly. 
For these reasons, rational use of marine protein sources and the formulation of nutritionally adequate aquafeeds, based on available and cost-effective alternative protein ingredients, are required in order to sustain the increasing development of aquaculture (Hasan 2001). Partial substitution of fishmeal using animal and plant alternative protein ingredients have been evaluated in diets for various cultured aquatic species with different results (Viyakarn et al. 1992; Pongmaneerat et al. 1993; Watanabe et al. 1993, 1997, 1998; Akiyama et al. 1995; Luzier et al. 1995; Riche and Brown 1999; Storebakken et al. 2000a; Satoh et al. 2003; Hernández et al. 2004).

Some of the main alternatives to be used as protein sources in fish feeds are plant ingredients, and many of them are widely available agro-industry by-products with very competitive prices (Tacon 1994; Aslaksen et al. 2007). The suitability of plant meals as dietary fishmeal substitutes in aquafeeds is highly dependent on the aquaculture species to be fed (Glencross et al. 2003; Glencross 2007). Salmonids as highly carnivorous fish need a high-quality (e.g. well balanced and highly digestible) protein source for optimum health and growth performance. Among potential plant raw materials, white lupin, with an elevated protein content (ca. 45) and a comparable energy content to fish meal, has been described as a feasible ingredient for the partial replacement of fishmeal in salmonid feeds. The substitution of fishmeal with lupin meal in diets for salmonid species has been reported with satisfactory results in terms of growth and digestibility by various authors (De la Higuera et al. 1988; Hughes 1988; Burel et al. 2000; Carter and Hauler 2000; Farhangi and Carter 2001; Bórquez and Alarcón 2002; Glencross et al. 2004; Glencross 2005). Chile has great potential for the production of grain legumes including lupin. This legume offers economic advantages over the use of other plant meals such as soybean, making it an attractive alternative source of protein in the national production of aquafeeds. Nevertheless, the potential to use different plant raw materials is related to the nutritional requirements of the species and should be properly studied (Guillaume and Metailler 1999). The use of legume seeds in most fish feeds is limited by the presence of endogenous antinutritional factors (ANFs) which accentuate digestive losses. Some ANFs are heat-labile and they are inactivated by heat treatment, which allows increased dietary levels at which such legumes can be utilized by fish (Tacon 1997; Fagbenro 1998). It is important that alternative plant feedstuffs present adequate bioavailability of nutrients, particularly digestible protein and energy. However, another important aspect to consider is the effect of the plant ingredient inclusion on the final quality of aquaculture products. The ingredient substitution could affect the fish by modifying the fatty acid composition of the feed (Storebakken et al. $2000 \mathrm{~b}$ ). An increase in the levels of $n-6$ polyunsaturated fatty acids (PUFAs) and a reduction in the levels of n-3 PUFAs in the tissues alter the nutritional value of the final product (Gomes et al. 1993; Torstensen et al. 2000; Bell et al. 2001; Caballero et al. 2002).

The present study was undertaken to evaluate the inclusion of whole lupin, Lupinus albus, var. Hamburgo, seed meal as a partial replacement for fishmeal in commercial extruded diets for rainbow trout, Oncorhynchus mykiss, with particular emphasis on the effect on growth performance, the apparent digestibility coefficient (ADC) (protein, lipids, carbohydrates, and energy), and muscle fatty acid composition.

\section{Materials and Methods}

A feeding trial was conducted to determine the responses of rainbow trout to increasing dietary percentages of whole lupin seed meal in commercial extruded diets. All of the experimental diets were formulated to be isonitrogenous and isoenergetic and contained approximately $45 \%$ crude protein and $5.5 \mathrm{kcal}$ g/diet. A fishmeal-based diet without whole lupin seed meal was used as positive control. Experimental diets were formulated to include whole lupin seed meal at 10, 15, and 20\%. The formulations were calculated using the software Single-Mix ${ }^{\circledR}$ for Windows (FORMAT International Ltd, London, UK). The diets were 
manufactured by Biomar Chile (Puerto Montt, Chile) using cooking extrusion technology. The formulation and chemical composition of the diets are shown in Table 1, while Table 2 shows the fatty acid profiles.

\section{Fish, Rearing Conditions, and Sampling}

The experiment was carried out during $12 \mathrm{wk}$ with rainbow trout at Los Laureles Experimental Fish Farm Station of the Universidad Católica de Temuco, Chile. A stock group of fish was fed with the control diet for a period of $10 \mathrm{~d}$ before the feeding experiment was initiated. Fish with an average body weight of about $65.9 \pm 15.1 \mathrm{~g}$ were randomly assigned in triplicate groups to four dietary treatments $(0,10,15$, and 20\% inclusion of whole lupin seed meal). Initially, the fish were distributed (46 fish/tank) at an average density of $10.7 \mathrm{~kg} / \mathrm{m}^{3}$ in twelve $0.3 \mathrm{~m}^{3}$ circular fiber glass tanks. However, after $8 \mathrm{wk}$ the fish were transferred to twelve $0.6 \mathrm{~m}^{3}$ tanks because of the size increment achieved. The water supply was permanent and the influx rate corresponded to 7.5 and $15 \mathrm{~L} / \mathrm{min}$ for the tanks of 0.3 and $0.6 \mathrm{~m}^{3}$, respectively. Average water temperature was $13.5 \pm 2.8 \mathrm{C}$ during the whole experimental period. Fish were fed manually twice per day, $7 \mathrm{~d}$ a week to apparent satiation.

In order to determine growth changes and to calculate feed performance parameters, fish from each tank were individually weighed at the beginning and at the end of the experiment. Fifteen fish were randomly sampled from the original stock of fish for initial analysis of fatty acids profile, body composition, and liver histology. All groups of fish were starved during $24 \mathrm{~h}$ and anesthetized with benzocaine (BZ20, Laboratorio Veterquimica, Chile) prior to weight measurement. At the end of the feeding trial, five fish per tank (15 per treatment) were randomly collected and euthanized. Body and liver weight of each fish were measured

TABLE 1. Formulation and composition of the experimental diets.

\begin{tabular}{|c|c|c|c|c|}
\hline & \multicolumn{4}{|c|}{ Experimental diets } \\
\hline & Control & L10 & L15 & L20 \\
\hline \multicolumn{5}{|l|}{ Ingredients $(\%)$} \\
\hline Fishmeal $^{1}$ & 46.7 & 42.6 & 40.6 & 38.0 \\
\hline Fish oil & 15.0 & 14.2 & 14.1 & 14.0 \\
\hline Whole-grain lupin ${ }^{2}$ & 0.0 & 10.0 & 15.0 & 20.0 \\
\hline Wheat flour & 22.6 & 16.2 & 13.3 & 13.3 \\
\hline Corn gluten ${ }^{3}$ & 8.0 & 8.0 & 8.0 & 8.0 \\
\hline Hydrolyzed feather meal ${ }^{4}$ & 7.0 & 7.0 & 7.0 & 7.0 \\
\hline Biomar premix & 0.7 & 0.7 & 0.7 & 0.7 \\
\hline Water & 0.8 & 1.3 & 1.3 & 1.1 \\
\hline \multicolumn{5}{|l|}{ Proximate composition $(\%)^{5}$} \\
\hline Dry matter & 92.50 & 95.61 & 92.36 & 91.73 \\
\hline Protein & 45.07 & 46.96 & 46.42 & 45.36 \\
\hline Lipid & 25.95 & 27.25 & 25.88 & 22.99 \\
\hline Ash & 8.13 & 8.26 & 7.98 & 7.98 \\
\hline Fiber & 0.74 & 1.48 & 2.22 & 2.05 \\
\hline Nitrogen-free extract & 20.11 & 16.05 & 17.50 & 21.62 \\
\hline Gross energy $(\mathrm{kcal} / \mathrm{g})$ & 5.62 & 5.58 & 5.62 & 5.47 \\
\hline
\end{tabular}

\footnotetext{
${ }^{1}$ Super Prime Chilean fish meal, steam-dried (Exapesca S.A., Talcahuano, Chile): $68 \%$ crude protein and $12 \%$ crude lipid.

${ }^{2}$ White lupin var. Hamburg (Sel Chile S.A., Temuco, Chile): $37.3 \%$ crude protein, $7.4 \%$ crude lipid, and total alkaloid $0.012 \%$.

${ }^{3}$ By-product from starch and corn oil industry (Graneles Chile S.A., Santiago, Chile): $60 \%$ crude protein and $3 \%$ crude lipid.

${ }^{4}$ By-product from poultry industry (Terramar Chile S.A., Santiago, Chile): $82 \%$ crude protein and $6 \%$ crude lipid.

${ }^{5}$ Data are given on a dry matter basis.
} 
TABLE 2. Fatty acid composition of the experimental diets. ${ }^{1}$

\begin{tabular}{|c|c|c|c|c|}
\hline & \multicolumn{4}{|c|}{ Experimental diets } \\
\hline & Control & L10 & L15 & L20 \\
\hline$\%$ Total lipid & $25.32 \pm 0.88$ & $23.74 \pm 0.86$ & $23.63 \pm 0.57$ & $24.70 \pm 0.39$ \\
\hline $\mathrm{C} 14: 0$ & $8.04 \pm 0.24$ & $8.49 \pm 2.16$ & $6.78 \pm 1.65$ & $6.49 \pm 0.26$ \\
\hline $\mathrm{C} 15: 0$ & $0.90 \pm 0.02$ & $0.91 \pm 0.17$ & $0.72 \pm 0.20$ & $0.66 \pm 0.01$ \\
\hline C16:0 & $20.80 \pm 0.09$ & $21.70 \pm 2.70$ & $19.24 \pm 1.63$ & $19.40 \pm 0.04$ \\
\hline $\mathrm{C} 17: 0$ & $0.97 \pm 0.04$ & $0.96 \pm 0.01$ & $1.06 \pm 0.17$ & $0.93 \pm 0.03$ \\
\hline C18:0 & $4.21 \pm 0.08$ & $4.17 \pm 0.16$ & $4.20 \pm 0.01$ & $4.24 \pm 0.07$ \\
\hline $\mathrm{C} 21: 0$ & $2.58 \pm 0.10$ & $2.40 \pm 0.21$ & $2.42 \pm 0.02$ & $2.30 \pm 0.01$ \\
\hline $\mathrm{C} 23: 0$ & $0.73 \pm 0.04$ & $0.39 \pm 0.55$ & $0.70 \pm 0.01$ & $0.64 \pm 0.01$ \\
\hline Total SAFA ${ }^{2}$ & $38.30 \pm 0.17$ & $39.36 \pm 4.07$ & $35.82 \pm 3.46$ & $35.09 \pm 0.28$ \\
\hline C16:1 & $6.47 \pm 0.04$ & $6.45 \pm 0.64$ & $5.61 \pm 0.30$ & $5.57 \pm 0.05$ \\
\hline $\mathrm{C} 17: 1$ & $1.04 \pm 0.07$ & $1.09 \pm 0.14$ & $1.00 \pm 0.00$ & $1.04 \pm 0.00$ \\
\hline C18:1n9 & $12.47 \pm 0.05$ & $12.85 \pm 0.44$ & $14.56 \pm 0.36$ & $15.33 \pm 0.07$ \\
\hline C20:1n9 & $1.46 \pm 0.05$ & $1.41 \pm 0.22$ & $1.49 \pm 0.20$ & $1.49 \pm 0.01$ \\
\hline C24:1n9 & $0.48 \pm 0.00$ & $0.42 \pm 0.01$ & $0.45 \pm 0.02$ & $0.45 \pm 0.05$ \\
\hline Total MUFA ${ }^{3}$ & $24.85 \pm 0.03$ & $25.00 \pm 0.06$ & $26.16 \pm 0.26$ & $26.94 \pm 0.11$ \\
\hline $\mathrm{C} 18: 2 \mathrm{n} 6 \mathrm{t}$ & $1.60 \pm 0.02$ & $1.65 \pm 0.25$ & $1.47 \pm 0.08$ & $1.46 \pm 0.02$ \\
\hline $\mathrm{C} 18: 2 \mathrm{n} 6 \mathrm{c}$ & $5.90 \pm 0.12$ & $6.19 \pm 0.35$ & $6.39 \pm 0.00$ & $6.76 \pm 0.07$ \\
\hline $\mathrm{C} 18: 3 \mathrm{n} 3$ & $1.27 \pm 0.06$ & $1.36 \pm 0.01$ & $1.58 \pm 0.06$ & $1.65 \pm 0.01$ \\
\hline C18:3n6 & $0.40 \pm 0.01$ & $0.37 \pm 0.00$ & $0.44 \pm 0.02$ & $0.42 \pm 0.03$ \\
\hline C20:3n6 & $0.50 \pm 0.04$ & $0.44 \pm 0.06$ & $0.42 \pm 0.05$ & $0.42 \pm 0.05$ \\
\hline C20:4n6 & $1.24 \pm 0.02$ & $1.23 \pm 0.06$ & $1.31 \pm 0.05$ & $1.33 \pm 0.04$ \\
\hline $\mathrm{C} 20: 5 \mathrm{n} 3$ & $11.63 \pm 0.09$ & $10.77 \pm 1.75$ & $11.48 \pm 0.93$ & $10.91 \pm 0.06$ \\
\hline C22:6n3 & $14.07 \pm 0.44$ & $13.50 \pm 2.69$ & $14.67 \pm 2.30$ & $14.34 \pm 0.03$ \\
\hline Total PUFA ${ }^{4}$ & $36.86 \pm 0.20$ & $35.64 \pm 4.13$ & $38.03 \pm 3.20$ & $37.96 \pm 0.17$ \\
\hline$\sum n-3^{5}$ & $26.97 \pm 0.29$ & $25.64 \pm 4.43$ & $27.73 \pm 3.29$ & $27.30 \pm 0.05$ \\
\hline$\sum n-6^{6}$ & $9.89 \pm 0.09$ & $10.00 \pm 0.30$ & $10.33 \pm 0.10$ & $10.66 \pm 0.12$ \\
\hline$\sum n-3^{1} / \sum n-6^{7}$ & $2.73 \pm 0.06$ & $2.57 \pm 0.52$ & $2.69 \pm 0.34$ & $2.56 \pm 0.02$ \\
\hline$\sum n-3 H{ }^{8} A^{8}$ & $25.69 \pm 0.35$ & $24.28 \pm 4.44$ & $26.15 \pm 3.23$ & $25.64 \pm 0.04$ \\
\hline $\mathrm{C} 18: \ln 9 / \mathrm{DHA}^{9}$ & $1.08 \pm 0.04$ & $1.17 \pm 0.20$ & $1.20 \pm 0.15$ & $1.27 \pm 0.01$ \\
\hline
\end{tabular}

HUFA = highly unsaturated fatty acid; MUFA = monounsaturated fatty acid; PUFA = polyunsaturated fatty acid; SAFA $=$ saturated fatty acid.

${ }^{1}$ Each value is the average \pm standard deviation $(n=6)$.

${ }^{2}$ Total saturated fatty acids, including fatty acids not listed.

${ }^{3}$ Total monounsaturated fatty acids, including fatty acids not listed.

${ }^{4}$ Total polyunsaturated fatty acids, including fatty acids not listed.

${ }^{5}$ Total omega- 3 fatty acids, including fatty acids not listed.

${ }^{6}$ Total omega- 6 fatty acids, including fatty acids not listed.

${ }^{7}$ Total omega-3: omega-6 ratio, including fatty acids not listed.

${ }^{8}$ Total omega-3 highly unsaturated fatty acids.

${ }^{9}$ Oleic acid : docosahexaenoic acid ratio.

and registered. Analyses of pooled whole body samples from each group of fish were made to determine protein, lipid, moisture, and ash. Pooled dorsal muscle samples (three fish per tank) from each treatment were collected and frozen at $-20 \mathrm{C}$ during $2 \mathrm{wk}$ for fatty acid profile analysis.

Thermal growth coefficient (TGC) was determined by the equation TGC $=\left(W_{\mathrm{f}}^{1 / 3}-W_{\mathrm{i}}^{1 / 3}\right) /$ $\sum(T \times D) \times 100$, where $W_{\mathrm{i}}$ and $W_{\mathrm{f}}$ are the initial and final weights (tank means), respectively, $D$ represents the number of feeding days, and $T$ corresponds to the average water temperature. Feed conversion ratio (FCR) was calculated as $\mathrm{FCR}=F / G$, where $F$ is consumption of dry matter from feed and $G$ is the weight gain. Hepatosomatic index (HSI) was calculated as $\mathrm{HSI}=100 \times(\mathrm{LW} / \mathrm{FW})$, where $\mathrm{LW}$ is the liver weight and FW represents the fish's body weight. 
ADCs were determined using an indirect quantification method with $\mathrm{Cr}_{2} \mathrm{O}_{3}$ as inert marker. Twelve tanks were stocked each with 65 fish $(30.08 \pm 9.95 \mathrm{~g})$. Fish were acclimatized to the tanks and to each dietary treatment during $10 \mathrm{~d}$ before initiating the fecal collection. Fish were fed manually twice a day, and feces were collected using a settlement column fecal collector as described by Cho et al. (1985). Feces were collected over a $7-\mathrm{d}$ period, pooled within the tank, and kept at $-80 \mathrm{C}$ before being freeze-dried for $48 \mathrm{~h}$ in preparation for analysis. Dry matter ADC (\%) was calculated by means of the formula $100 \times\left[1-\left(\% I_{\text {feed }} / \% I_{\text {feces }}\right)\right]$ and ADC of the nutrients $(\%)$ as $100-\left[100\left(\% I_{\text {feed }} / \% I_{\text {feces }}\right) \times\right.$ $\left.\left(\% N_{\text {feed }} / \% N_{\text {feces }}\right)\right]$, where $I$ is the inert marker and $N$ the nutrient. The digestible energy (DE) was calculated according to De la Higuera et al. $(1988)$ as $\mathrm{DE}=\left(F_{\text {protein }} \times \mathrm{ADC}_{\text {protein }} \times E_{\text {protein }}\right)$ $+\left(F_{\text {lipid }} \times \mathrm{ADC}_{\text {lipid }} \times E_{\text {lipid }}\right)+\left(F_{\text {nitrogen-free extract }}\right.$ $\left.\times \mathrm{ADC}_{\text {nitrogen-freeextract }} \times E_{\text {nitrogen-free extract }}\right)$, where $F$ is the nutrient content of the feed $(\mathrm{g})$, $\mathrm{ADC}$ is the apparent digestibility of the nutrient, and $E$ is the theoretical energy content $(\mathrm{kJ} / \mathrm{g})$.

\section{Chemical Analysis}

The proximate compositions (crude protein, crude lipid, total fiber, ash, and moisture) of diets, feces, and carcass were determined according to AOAC (1998). Dry matter was calculated by gravimetric analysis following oven-drying at $105 \mathrm{C}$ for $24 \mathrm{~h}$. Chromic oxide levels were determined spectrophotometrically following the digestion and oxidation of samples using a modification from Furukawa and Tsukahara (1966). Protein levels were calculated from the determination of total nitrogen by Kjeldahl digestion, based on $\mathrm{N} \times 6.25$. Fat content was determined gravimetrically following extraction of the lipids with solvent (Soxhlet). Ash content was determined gravimetrically following loss of mass after combustion of a sample in a muffle furnace at $550 \mathrm{C}$ for 3 h. Fiber content was calculated by gravimetric analysis following oven-drying at $105 \mathrm{C}$ for $24 \mathrm{~h}$, after acid and alkali digestion with sulfuric acid and sodium hydroxide, respectively. Nitrogen-free extract (NFE) content was determined by difference. The gross energy in diets was estimated assuming a theoretical energetic content of $5.6,9.5$, and $4.1 \mathrm{kcal} / \mathrm{g}$ for the proteins, lipids, and carbohydrates, respectively (Cho et al. 1982).

The total lipids of diet and dorsal muscle samples were extracted according to Folch et al. (1957), from a 1-g sample which was homogenized in a chloroform/methanol solution $(2: 1 ; \mathrm{v} / \mathrm{v})$ and $0.01 \%$ butyl hydroxytoluene (BHT). Fatty acids methyl esters (FAME) were prepared by acid catalysis transmethylation of total lipids (Morrison and Smith 1964). FAME were analyzed using a Hewlett Packard gas chromatograph (model HP6890 GC System, Elisan, USA), equipped with an FID detector and a fused silica capillary column SP2398 (30 m, $0.25 \mathrm{~mm}$ id, $0.20 \mu \mathrm{m}$ film thickness), using helium as carrier gas. The initial oven temperature was $60 \mathrm{C}$. One minute after injection of the sample the temperature was increased to $245 \mathrm{C}$ at a rate of $4 \mathrm{C}$. This temperature was maintained for an additional $5 \mathrm{~min}$. Fatty acids were identified by reference to the Supelco-37 standard, expressed as a percentage of the area, according to the total fatty acids identified.

\section{Histological Analysis}

The liver samples were fixed in Bouin alcohol, dehydrated in ethanol, and immersed in paraffin. The cut sections $(4-6 \mu \mathrm{m})$ were stained using haematoxylin and eosin, for observation under the microscope.

\section{Statistical Analysis}

The results were analyzed using the programme StatMost version 3.0 for Windows (Dataxiom Software Inc., Los Angeles, CA, USA). Significant differences $(P<0.05)$ between dietary treatments were determined by one-way analysis of variance (ANOVA). Differences between means were determined by Tukey's test. Before the application of the ANOVA, the presumed homogeneity of variances was verified through the Bartlett test. 
Arcsine transformation was applied to data expressed as percentages. The normality of the data was confirmed using the KolmogorovSmirnov test.

\section{Results}

All experimental diets were well accepted by the fish during the $12 \mathrm{wk}$ of the experiment. The survival rate was nearly $95 \%$ for all treatments. Table 3 shows the results obtained for growth and feeding parameters. Final weight ranged from $236 \mathrm{~g}$ (control) to $260 \mathrm{~g}$ (L20), and no significant differences in growth occurred among treatments $(P>0.05)$.

No differences were observed in daily feed consumption. FCR was similar for all the treatments. TGC ranged between 0.17 and 0.19 , and values were not significantly different $(P>$ 0.05) among the dietary treatments.

The initial and final body compositions and HSI of the fish are shown in Table 4. In general, the inclusion of whole-grain lupin in the diets did not significantly affect the proximate composition of the fish compared to the control diet. Nevertheless, among the treatments with lupin inclusion, only protein content was different between L15 and L10 diets $(P<0.05)$. On the other hand, at the end of the growth trial, fish in all treatments exhibited a significant decrease in protein, dry matter, and ash content, and a significant increase in lipid content $(P<0.05)$ compared to the initial body composition. HSI did not differ between treatments, with values close to $1.0 \%$. However, these values were significantly lower $(P<0.05)$ than those determined at the beginning of the experiment.

Liver histology of fish fed diets with lupin was similar to fish fed the control diet. Some lesions due to infiltration of fat in the hepatocytes were observed for all of the treatments compared to the initial state of the livers.

ADC values for all the experimental diets were not significantly different (Table 5). ADC

TABLE 3. Growth and feeding parameters in rainbow trout fed with different experimental diets. ${ }^{1}$

\begin{tabular}{lcccc}
\hline & \multicolumn{4}{c}{ Experimental diets } \\
\cline { 2 - 5 } Parameter & Control & L10 & L15 & L20 \\
\hline Initial weight $(\mathrm{g})$ & $65.9 \pm 15.1$ & $65.9 \pm 15.1$ & $65.9 \pm 15.1$ & $65.9 \pm 15.1$ \\
Final weight $(\mathrm{g})$ & $236.1 \pm 56.1$ & $255.7 \pm 59.9$ & $242.1 \pm 67.2$ & $260.5 \pm 57.4$ \\
\% weight increase & $258.2 \pm 15.4$ & $281.3 \pm 15.4$ & $268.5 \pm 28.1$ & $295.3 \pm 35.4$ \\
Daily feed intake $(\mathrm{g})$ & $98.7 \pm 9.7$ & $100.8 \pm 4.9$ & $105.0 \pm 6.9$ & $95.2 \pm 1.2$ \\
FCR $^{2}$ & $1.07 \pm 0.12$ & $1.0 \pm 0.03$ & $1.16 \pm 0.04$ & $1.02 \pm 0.03$ \\
TGC $^{3}$ & $0.17 \pm 0.00$ & $0.18 \pm 0.01$ & $0.17 \pm 0.01$ & $0.19 \pm 0.02$ \\
\hline
\end{tabular}

${ }^{1}$ Each value is the average \pm standard deviation $(n=3)$. None of the values was significantly different.

${ }^{2}$ Feed conversion ratio.

${ }^{3}$ Standard growth rate. Thermal growth coefficient.

TABLE 4. Body composition and hepatosomatic index of rainbow trout, Oncorhyncus mykiss, fed with different experimental diets. ${ }^{1}$

\begin{tabular}{lccrcc}
\hline \multirow{2}{*}{$\begin{array}{l}\text { Proximate } \\
\text { composition (\%) }\end{array}$} & \multicolumn{4}{c}{ Experimental diets } \\
\cline { 3 - 6 } & Initial & Control & L10 & L15 & L20 \\
\hline Dry matter & $28.29^{\mathrm{a}}$ & $23.77 \pm 0.92^{\mathrm{cb}}$ & $25.37 \pm 0.65^{\mathrm{ac}}$ & $21.27 \pm 1.72^{\mathrm{b}}$ & $23.98 \pm 0.98^{\mathrm{cb}}$ \\
Protein & $18.88^{\mathrm{a}}$ & $13.34 \pm 0.81^{\mathrm{bc}}$ & $14.96 \pm 1.58^{\mathrm{b}}$ & $11.40 \pm 0.37^{\mathrm{c}}$ & $13.09 \pm 0.71^{\mathrm{bc}}$ \\
Lipid & $5.99^{\mathrm{a}}$ & $8.66 \pm 0.98^{\mathrm{ab}}$ & $10.27 \pm 1.37^{\mathrm{ab}}$ & $10.59 \pm 1.26^{\mathrm{b}}$ & $7.90 \pm 0.29^{\mathrm{b}}$ \\
Ash & $2.66^{\mathrm{a}}$ & $1.63 \pm 0.35^{\mathrm{b}}$ & $2.07 \pm 0.11^{\mathrm{ab}}$ & $1.41 \pm 0.27^{\mathrm{b}}$ & $1.99 \pm 0.18^{\mathrm{ab}}$ \\
HSI $^{2}$ & $1.9 \pm 0.32^{\mathrm{a}}$ & $1.1 \pm 0.27^{\mathrm{b}}$ & $1.0 \pm 0.18^{\mathrm{b}}$ & $1.1 \pm 0.12^{\mathrm{b}}$ & $1.1 \pm 0.23^{\mathrm{b}}$ \\
\hline
\end{tabular}

\footnotetext{
${ }^{1}$ Each value is the average \pm standard deviation $(n=3)$. Values in the same row with distinct superscripts are significantly different $(P<0.05)$. Data are given on a wet weight basis.

${ }^{2}$ Hepatosomatic index.
} 
TABLE 5. Apparent digestibility coefficients and digestible energy for the experimental diets. ${ }^{1}$

\begin{tabular}{llccr}
\hline & \multicolumn{4}{c}{ Experimental diets } \\
\cline { 2 - 5 } & Control & L10 & L15 & L20 \\
\hline Dry matter & $84.80 \pm 1.83$ & $83.90 \pm 0.96$ & $86.88 \pm 1.77$ & $86.46 \pm 1.38$ \\
Protein & $92.77 \pm 0.65$ & $92.23 \pm 0.36$ & $94.32 \pm 0.74$ & $94.35 \pm 0.71$ \\
Lipid & $98.93 \pm 0.33$ & $95.28 \pm 0.33$ & $97.29 \pm 0.38$ & $98.36 \pm 0.32$ \\
Nitrogen-free extract & $75.70 \pm 3.07$ & $70.06 \pm 0.02$ & $76.91 \pm 2.50$ & $78.83 \pm 0.37$ \\
Digestible energy (MJ/kg) & $22.66 \pm 0.24$ & $22.51 \pm 0.08$ & $22.74 \pm 0.02$ & $22.12 \pm 0.12$ \\
\hline
\end{tabular}

${ }^{1}$ Each value is the average \pm standard deviation $(n=3)$. Data are given in dry matter basis.

values for dry matter varied between $83.9 \%$ (L10) and $86.5 \%$ (L20). The highest ADC values were found for lipids, followed by protein, while the lowest coefficients were obtained for carbohydrates.

Dorsal muscle fatty acid compositions of fish fed experimental diets are reported in Table 6. The percentage of saturated fatty acids (SAFAs) was not affected by the incorporation of wholegrain lupin. The most abundant fatty acid was palmitic acid (C16:0). This fatty acid decreased with increasing levels of dietary lupin; however, this was not significant.

The total amount of monounsaturated fatty acids (MUFAs) had a slight tendency to increase, but there were no significant differences between the control diet and the diets with lupin. However, the initial MUFA content of the muscle was significantly increased in all treatments $(P<0.05)$ because of the significant increases in palmitoleic (C16:1) and elaidic (C18:1n-9 trans) acids.

The total PUFAs had a slight tendency to increase as the percentage of lupin in the feed increased, although this was not significant $(P>0.05)$. There was no difference for the different diets in the $n-6$ PUFA content of the muscle; however, the linoleic (C18:2n-6 cis) and arachidonic (C20:4n-6) acids decreased by the end of the experiment as compared to the initial levels $(P<0.05)$.

The percentage of linoleic acid (C18:3n-3) varied between $0.85 \%$ (L10) and $1.19 \%$ (L20), and the values for eicosapentaenoic acid (EPA, C20:5n-3) fluctuated between $6.08 \%$ (control) and $7.5 \%$ (L20).

The docosahexaenoic acid (DHA; C22:6n3 ) in the muscle was constant between the treatments. These percentages were slightly greater than those present in the diets, although not significantly different $(P>0.05)$.

Despite the decrease in the total n-6 PUFAs, the $\mathrm{n}-3 / \mathrm{n}-6$ ratio was not affected by the diets $(P>0.05)$. However, the $\mathrm{C} 18: 1 \mathrm{n}-9 / \mathrm{DHA}$ ratio in the muscle was similar $(P>0.05)$ between the dietary treatments.

\section{Discussion}

This study demonstrated the potential for using whole-grain lupin in commercial rainbow trout feed, in agreement with the previously reported studies on salmonids (De la Higuera et al. 1988; Burel et al. 1998, 2000; Carter and Hauler 2000; Farhangi and Carter 2001; Glencross 2007). In general, the growth performances obtained in the fish fed diets with whole grain lupin, regardless of the percentage incorporated, were similar to those obtained with the control diet.

Lupin contains antinutritional factors, principally alkaloids (Tacon 1997; Aslaksen et al. 2007), which could affect the feed intake because of palatability issues (De la Higuera et al. 1988). However, in agreement with Morales et al. (1994), feed intake recorded in this experiment was not influenced by dietary lupin concentration. Further, the variety used in this study was a sweet type, with low levels of alkaloids, below $100 \mathrm{mg} / \mathrm{kg}$ (Petterson et al. 1997, 2000).

Although weight gain has been shown to decrease with increasing dietary lupin in the previous studies (De la Higuera et al. 1988; Hughes 1991), the low levels of dietary inclusion in the present experiment had no effect. 
TABLE 6. Profile of fatty acids present in the muscle of rainbow trout fed with different experimental diets. ${ }^{1}$

\begin{tabular}{|c|c|c|c|c|c|}
\hline & \multirow[b]{2}{*}{ Initial } & \multicolumn{4}{|c|}{ Experimental diets } \\
\hline & & Control & L10 & L15 & L20 \\
\hline$\%$ Total lipid & $1.30 \pm 0.36^{\mathrm{a}}$ & $2.25 \pm 1.85^{\mathrm{a}}$ & $4.34 \pm 0.78^{a}$ & $4.66 \pm 2.08^{a}$ & $5.34 \pm 4.07^{\mathrm{a}}$ \\
\hline $\mathrm{C} 14: 0$ & $3.03 \pm 0.62^{\mathrm{a}}$ & $5.89 \pm 0.42^{\mathrm{b}}$ & $6.41 \pm 0.55^{\mathrm{b}}$ & $5.70 \pm 0.49^{b}$ & $5.43 \pm 0.59^{b}$ \\
\hline $\mathrm{C} 16: 0$ & $28.24 \pm 5.00^{\mathrm{a}}$ & $28.13 \pm 2.97^{\mathrm{a}}$ & $25.64 \pm 1.19^{\mathrm{ab}}$ & $22.88 \pm 0.99^{\mathrm{ab}}$ & $21.78 \pm 2.29^{b}$ \\
\hline $\mathrm{C} 17: 0$ & $0.00 \pm 0.00^{\mathrm{a}}$ & $0.69 \pm 0.10^{\mathrm{b}}$ & $0.84 \pm 0.31^{\mathrm{b}}$ & $0.75 \pm 0.44^{\mathrm{b}}$ & $0.58 \pm 0.14^{\mathrm{b}}$ \\
\hline C18:0 & $7.06 \pm 0.91^{\mathrm{a}}$ & $6.41 \pm 1.43^{\mathrm{ab}}$ & $4.98 \pm 0.53^{\mathrm{a}}$ & $4.68 \pm 0.28^{\mathrm{b}}$ & $4.47 \pm 0.65^{\mathrm{b}}$ \\
\hline $\mathrm{C} 21: 0$ & $0.67 \pm 0.15^{\mathrm{a}}$ & $0.89 \pm 0.09^{\mathrm{b}}$ & $1.00 \pm 0.05^{\mathrm{b}}$ & $1.21 \pm 0.11^{\mathrm{b}}$ & $1.25 \pm 0.13^{\mathrm{b}}$ \\
\hline $\mathrm{C} 23: 0$ & $0.00 \pm 0.00^{\mathrm{a}}$ & $0.67 \pm 0.20^{\mathrm{b}}$ & $0.82 \pm 0.05^{\mathrm{b}}$ & $0.89 \pm 0.10^{\mathrm{b}}$ & $0.95 \pm 0.10^{\mathrm{b}}$ \\
\hline Total SAFA ${ }^{2}$ & $39.01 \pm 6.68^{\mathrm{a}}$ & $44.00 \pm 4.67^{\mathrm{a}}$ & $38.91 \pm 2.09^{\mathrm{a}}$ & $37.31 \pm 1.09^{\mathrm{a}}$ & $35.60 \pm 2.70^{\mathrm{a}}$ \\
\hline $\mathrm{C} 16: 1$ & $3.62 \pm 0.33^{\mathrm{a}}$ & $5.94 \pm 0.64^{\mathrm{b}}$ & $6.19 \pm 0.36^{b}$ & $6.71 \pm 0.47^{\mathrm{b}}$ & $6.33 \pm 0.68^{b}$ \\
\hline $\mathrm{C} 17: 1$ & $0.00 \pm 0.00^{\mathrm{a}}$ & $0.80 \pm 0.06^{\mathrm{b}}$ & $0.84 \pm 0.05^{\mathrm{b}}$ & $0.93 \pm 0.08^{\mathrm{b}}$ & $0.84 \pm 0.15^{\mathrm{b}}$ \\
\hline C18:1n9 & $14.12 \pm 0.44^{\mathrm{a}}$ & $17.06 \pm 0.78^{\mathrm{b}}$ & $16.95 \pm 1.14^{\mathrm{b}}$ & $19.25 \pm 1.14^{\mathrm{bc}}$ & $19.92 \pm 1.02^{\mathrm{c}}$ \\
\hline C20:1n9 & $0.89 \pm 0.19^{\mathrm{a}}$ & $1.33 \pm 0.68^{\mathrm{a}}$ & $1.55 \pm 0.17^{\mathrm{a}}$ & $1.34 \pm 0.67^{\mathrm{a}}$ & $1.85 \pm 0.21^{\mathrm{a}}$ \\
\hline C24:1n9 & $0.00 \pm 0.00^{\mathrm{a}}$ & $0.40 \pm 0.06^{\mathrm{b}}$ & $0.36 \pm 0.21^{\mathrm{b}}$ & $0.37 \pm 0.17^{\mathrm{b}}$ & $0.23 \pm 0.24^{\mathrm{b}}$ \\
\hline Total MUFA ${ }^{3}$ & $21.45 \pm 0.21^{\mathrm{a}}$ & $28.59 \pm 1.64^{b}$ & $29.20 \pm 1.50^{\mathrm{b}}$ & $31.74 \pm 1.83^{b}$ & $32.69 \pm 2.11^{\mathrm{b}}$ \\
\hline $\mathrm{C} 18: 2 \mathrm{n} 6 \mathrm{t}$ & $0.00 \pm 0.00^{\mathrm{a}}$ & $0.80 \pm 0.08^{\mathrm{b}}$ & $0.86 \pm 0.08^{b}$ & $0.73 \pm 0.43^{\mathrm{b}}$ & $0.95 \pm 0.17^{\mathrm{b}}$ \\
\hline $\mathrm{C} 18: 2 \mathrm{n} 6 \mathrm{c}$ & $6.65 \pm 0.11^{\mathrm{a}}$ & $3.54 \pm 0.26^{\mathrm{bc}}$ & $3.42 \pm 0.18^{\mathrm{b}}$ & $3.85 \pm 0.21^{\mathrm{bc}}$ & $4.10 \pm 0.26^{\mathrm{c}}$ \\
\hline $\mathrm{C} 18: 3 \mathrm{n} 3$ & $1.00 \pm 0.01^{\mathrm{a}}$ & $0.91 \pm 0.44^{\mathrm{a}}$ & $0.85 \pm 0.04^{\mathrm{a}}$ & $1.19 \pm 0.23^{\mathrm{a}}$ & $1.19 \pm 0.10^{\mathrm{a}}$ \\
\hline C18:3n6 & $0.00 \pm 0.00^{\mathrm{a}}$ & $0.40 \pm 0.22^{\mathrm{a}}$ & $0.23 \pm 0.12^{\mathrm{a}}$ & $0.13 \pm 0.15^{\mathrm{a}}$ & $0.16 \pm 0.06^{\mathrm{a}}$ \\
\hline $\mathrm{C} 20: 2$ & $0.63 \pm 0.21^{\mathrm{a}}$ & $0.63 \pm 0.13^{b}$ & $0.63 \pm 0.16^{\mathrm{ab}}$ & $0.45 \pm 0.16^{\mathrm{ab}}$ & $0.36 \pm 0.07^{\mathrm{ab}}$ \\
\hline C20:4n6 & $2.17 \pm 0.93^{\mathrm{a}}$ & $1.05 \pm 0.06^{\mathrm{a}}$ & $0.86 \pm 0.38^{\mathrm{a}}$ & $1.12 \pm 0.18^{\mathrm{a}}$ & $0.82 \pm 0.35^{\mathrm{a}}$ \\
\hline $\mathrm{C} 20: 5 \mathrm{n} 3$ & $6.73 \pm 0.04^{\mathrm{a}}$ & $6.08 \pm 1.01^{\mathrm{a}}$ & $6.68 \pm 0.43^{\mathrm{a}}$ & $7.46 \pm 0.28^{\mathrm{a}}$ & $7.46 \pm 0.57^{\mathrm{a}}$ \\
\hline $\mathrm{C} 22: 6 \mathrm{n} 3$ & $22.37 \pm 7.69^{\mathrm{a}}$ & $13.43 \pm 2.92^{\mathrm{b}}$ & $15.82 \pm 1.52^{\mathrm{ab}}$ & $15.61 \pm 1.62^{\mathrm{ab}}$ & $16.24 \pm 1.64^{\mathrm{ab}}$ \\
\hline Total PUFA ${ }^{4}$ & $39.54 \pm 6.89^{\mathrm{a}}$ & $27.41 \pm 3.43^{\mathrm{bc}}$ & $29.91 \pm 1.72^{\mathrm{bc}}$ & $30.95 \pm 1.51^{\mathrm{bc}}$ & $31.71 \pm 2.13^{\mathrm{ac}}$ \\
\hline$\sum n-3^{5}$ & $30.10 \pm 7.72^{\mathrm{a}}$ & $20.62 \pm 3.53^{\mathrm{b}}$ & $23.43 \pm 1.81^{\mathrm{b}}$ & $24.32 \pm 1.81^{\mathrm{b}}$ & $24.95 \pm 1.90^{\mathrm{b}}$ \\
\hline$\sum n-3$ HUFA $^{6}$ & $29.10 \pm 7.73^{\mathrm{a}}$ & $19.71 \pm 3.84^{b}$ & $22.58 \pm 1.81^{\mathrm{b}}$ & $23.13 \pm 1.72^{\mathrm{b}}$ & $23.76 \pm 1.87^{b}$ \\
\hline$\sum n-6^{7}$ & $9.44 \pm 0.83$ & $6.73 \pm 0.17$ & $6.48 \pm 0.18$ & $6.63 \pm 0.64$ & $6.76 \pm 0.31$ \\
\hline$\sum n-3^{1} / \sum n-6^{8}$ & $3.24 \pm 1.10^{\mathrm{a}}$ & $3.07 \pm 0.53^{\mathrm{a}}$ & $3.62 \pm 0.35^{\mathrm{a}}$ & $3.71 \pm 0.60^{\mathrm{a}}$ & $3.69 \pm 0.21^{\mathrm{a}}$ \\
\hline C18:1n9/DHA ${ }^{9}$ & $0.81 \pm 0.28^{\mathrm{a}}$ & $1.53 \pm 0.30^{\mathrm{bc}}$ & $1.27 \pm 0.17^{\mathrm{ac}}$ & $1.44 \pm 0.23^{\mathrm{bc}}$ & $1.44 \pm 0.16^{\mathrm{bc}}$ \\
\hline
\end{tabular}

HUFA = highly unsaturated fatty acid; MUFA = monounsaturated fatty acid; PUFA = polyunsaturated fatty acid; SAFA $=$ saturated fatty acid.

${ }^{1}$ Each value is the average \pm standard deviation $(n=6)$.

${ }^{2}$ Total saturated fatty acids, including fatty acids not listed.

${ }^{3}$ Total monounsaturated fatty acids, including fatty acids not listed.

${ }^{4}$ Total polyunsaturated fatty acids, including fatty acids not listed.

${ }^{5}$ Total omega-3 fatty acids, including fatty acids not listed.

${ }^{6}$ Total omega-3 highly unsaturated fatty acids.

${ }^{7}$ Total omega- 6 fatty acids including fatty acids not listed.

${ }^{8}$ Total omega-3 : omega-6 ratio, including fatty acids not listed.

${ }^{9}$ Oleic acid : docosahexaenoic acid ratio.

According to Farhangi and Carter (2001) and Burel et al. (2000), only inclusion of over $40 \%$ of $L$. albus in diets supplemented with amino acids caused a reduction in the weight gain in rainbow trout.

The TGC obtained in the experiment matched normal values reported for rainbow trout, which ranged between 0.153 and 0.203 (Bureau and Cho 1999). No effects on TGC have been demonstrated for lupin substitutions (Glencross et al. 2002), which suggests that the TGC values found were independent of the feeds tested, although they were lower than the values reported in the works cited.

Whole-body composition did not vary despite lupin inclusion, coinciding with the results of other studies where higher levels of lupine meal were included (Hughes 1991; Gouveia et al. 1993; Burel et al. 1998; Bórquez and Alarcón 2002; Carter and Hauler 2000; Bransden et al. 2001). However, the percentages of protein and lipid were lower than those achieved by these 
studies, basically because of differences in fish sizes in each trial and whether the values are expressed in dry or wet basis.

The excess of lipids in the hepatic cells cannot be ascribed exclusively to the use of lupin because it was also observed in the control. The effect of the inclusion of legumes, such as lupin and peas, in the diet is characterized by an increase in lipid deposits and a reduction of glycogen in the hepatocytes (Robaina et al. 1995; Russell et al. 2001). Likewise, other factors such as a deficiency of highly unsaturated fatty acids (HUFAs) in the diet and a high density of fish in the tanks could provoke an increase in lipid deposits in the liver (Montero et al. 2001; Caballero et al. 2002). However, these alterations did not affect the HSI.

The ADC of dry matter, crude protein, and lipid found in this study were similar to those reported in salmonids (De la Higuera et al. 1988; Carter and Hauler 2000; Glencross et al. 2004) and turbot (Burel et al. 2000) when lupin meal was included in the extruded diets. Despite the fact that DE of legumes is considered low on account of their high carbohydrate content (Morales et al. 1994), the values of $\mathrm{DE}$ in the experiment were similar to those reported by Gomes et al. (1993) probably because of an improvement resulted by the extrusion process.

The fatty acid profile in rainbow trout muscle was directly related to the fatty acid profile of the respective feeds (Watanabe 1982; Bell et al. 1986, 2001; Gomes et al. 1993; Guillou et al. 1995; Henderson 1996; Montero et al. 2001; Caballero et al. 2002). When the amount of lupin was increased in the diets, a slight decrease in the total percentage of SAFA was noted in the muscle. This is particularly characteristic when low SAFA levels, plant ingredients-based feeds are offered because they cause a reduction of palmitic acid in the muscle (Gomes et al. 1993).

The high growth rate of farmed salmon is the result of the use of feeds rich in energy content, principally MUFAs, including oleic acid (Bell et al. 2001). The MUFA concentrations increase when lupin is used in the feed because plant proteins contain 18:1(n-9) as a major fatty acid, although this was not significant in the present experiment (Table 2), resulting in the accumulation of this fatty acid in the tissues of fish fed these protein sources (Gomes et al. 1993; Bell et al. 2001; Caballero et al. 2002); as observed in this work, fillet from fish fed diet L20 showed a significantly higher oleic acid content compared to fillet from control and L10, and however, not different from fish fed L15 (Table 6). This accumulation is a consequence of this species being unable to desaturate 18:1(n-9) into $18: 3(n-3)$ or 18:2(n-6) (Storebakken et al. 2000b; Montero et al. 2001).

Another effect associated with the inclusion of plant protein sources is the increase in the n-6 PUFAs in the muscle, which is particularly high in lupin seeds (Yañez et al. 1983; Masson and Mella 1985; Petterson et al. 1997). Nevertheless, in the present study, with the inclusion of lupin in the diets, the 18:2n-6 levels in the muscle were similar to the control (Table 6), probably as a consequence of the minimum variation of n-6 fatty acid content in the experimental diets (Table 2). Similarly, the levels of 20:4n-6 did not vary among the treatments.

Lupin seed contains 9\% linolenic acid (Yañez et al. 1983; Masson and Mella 1985; Petterson et al. 1997) and therefore its inclusion in the feeds could help to maintain a constant content of this fatty acid, as well as that of EPA and DHA. Adverse effects occur when using other plant ingredients which decrease the 18:3 n-3 in the tissues (Gomes et al. 1993; Guillou et al. 1995; Henderson 1996; Bell et al. 2001; Caballero et al. 2002).

The existence of a higher quantity of DHA in the muscle in comparison to that contained in the feed is in agreement with the studies conducted by Gomes et al. (1993) and Bell et al. (2001). According to these authors, this is a result of a selective accumulation of DHA in the muscle even though the amount in the feed is low. However, in the present trial, the DHA level in the muscles may be explained by the high fish meal and oil in all experimental diets.

The reduction in the initial percentages of n-6 and n-3 PUFAs may be due to the nutritional quality of the feed ingested by the fish before the experiment (Shearer 1994) or due to 
the changes in the fatty acid profile produced by growth (Sheridan et al. 1985). Despite the fact that the quantity of lipids contributed by the lupin is small, the high proportion of $n-6$ series fatty acids causes an imbalance in the n-3/n-6 ratio (Robaina et al. 1995). However, this coefficient in the muscle is not affected by the diets because of the abundance of $n-3$ series PUFAs contributed by the fish oil, and in part by the lupin grain, and consequently our results were contrary to those reported with the use of other plant protein meals, where a reduction of the n-3/n- 6 ratio is observed as a result of an increase in 18:2n-6 and a decrease in the percentage of n-3 PUFAs (Gomes et al. 1993).

The products of Chilean salmon farming are of high nutritional value, with an abundance of n-3 series HUFAs and a high n-3/n-6 PUFA ratio. The consumption of such products represents a valuable benefit to human health including the prevention of cardiovascular diseases (Corraze 1999). From a consumer viewpoint, it is essential that a high $n-3 / n-6$ ratio is maintained in farmed fish. The use of plant proteins needs to be monitored carefully as these raw materials are known to influence the fatty acid profile of the final product (Bell et al. 2001). The use of fatty acid composition as a quality indicator of fish for human consumption shows that the inclusion of up to $20 \%$ of wholegrain white lupin in the extruded diets does not significantly alter the nutritional quality of the final product. On the other hand, although the inclusion of whole-grain white lupin in the extruded diets did not present technical or nutritional problems in the tested levels, further research should be carried out on the potential use of different species and varieties of lupin in aquafeeds for salmonids.

\section{Acknowledgments}

The authors want to express their appreciation to Biomar Chile for their kind co-operation in the preparation of the experimental diets. This study was partially funded by the FONDEF Project D06I1014.

\section{Literature Cited}

Akiyama, T., T. Unuma, T. Yamamoto, P. Marcouli, and S. Kishi. 1995. Combinational use of malt protein flour and soybean meal as alternative protein sources of fish meal in fingerling rainbow trout diets. Fisheries Science 61:828-832.

AOAC (Association of Official Analytical Chemists). 1998. Official method of analysis of the Association of Analytical Chemist, 16th edition. AOAC, Washington, DC, USA.

Aslaksen, M. A., O. F. Kraugerud, M. Penn, B. Svihus, V. Denstadli, H. Y. Jørgensen, M. Hillestad, Å. Krogdahl, and T. Storebakken. 2007. Screening of nutrient digestibilities and intestinal pathologies in Atlantic salmon, Salmo salar, fed diets with legumes, oilseeds, or cereals. Aquaculture 272: 541-555

Barlow, S. 2000. Fishmeal and fish oil: sustainable feed ingredients for aquafeeds. Global Aquaculture Advocate $4: 85-88$.

Bell, M. V., R. J. Henderson, and J. R. Sargent. 1986. The role of polyunsaturated fatty acids in fish. Comparative Biochemistry and Physiology 83B: 711-719.

Bell, J. G., J. McEvoy, D. R. Tocher, F. McGhee, P. J. Campbell, and J. R. Sargent. 2001. Replacement of fish oil with rapeseed oil in diets of Atlantic salmon (Salmo salar) affects tissue lipid compositions and hepatocyte fatty acid metabolism. Journal of Nutrition 131:1535-1543.

Bureau, D. P. and C. Y. Cho. 1999. Nutrition and feeding of fish. OMNR Fish Culture Course, University of Guelph, Guelph, Ontario, Canada.

Burel, C., T. Boujard, G. Corraze, S. J. Kaushik, G. Boeuf, K. A. Mol, S. Van Der Geyten, and E. R. Kuhn. 1998. Incorporation of high levels of extruded lupine in diets for rainbow trout (Oncorhynchus mykiss): nutritional value and effect on thyroid status. Aquaculture 163:323-343.

Burel, C., T. Boujard, F. Tulli, and S. J. Kaushik. 2000. Digestibility of extruded peas, extruded lupine, and rapeseed meal in rainbow trout (Oncorhynchus mykiss) and turbot (Psetta maxima). Aquaculture: 18:285-298.

Bórquez, A. and P. Alarcón. 2002. Reemplazo parcial de la harina de pescado por lupino blanco (Lupinus albus) en dietas para salmón del Atlántico (Salmo salar). Salmonicultura 28:17-19.

Bransden, M. P., C. G. Carter, and B. F. Nowak. 2001. Effects of dietary protein source on growth, immune function, blood chemistry and disease resistance of Atlantic salmon (Salmo salar L.) parr. Animal Science 73:105-114.

Caballero, M. J., A. Obach, G. Rosenlund, D. Montero, M. Gisvold, and M. S. Izquierdo. 2002. Impact of different dietary lipid sources on growth, lipid 
digestibility, tissue fatty acid composition and histology of rainbow trout, Oncorhynchus mykiss. Aquaculture 214:253-271.

Carter, C. G. and R. C. Hauler. 2000. Fish meal replacement by plant meals in extruded feeds for Atlantic salmon, Salmo salar L. Aquaculture 185: 299-311.

Cho, C. Y., S. J. Slinger, and H. S. Bayley. 1982. Bioenergetics of salmonid fishes: energy intake, expenditure and productivity. Comparative Biochemistry and Physiology 73B:2-41.

Cho, C. Y., C. Cowey, and T. Watanabe. 1985. Finfish nutrition in Asia. Methodological approaches to research and development. IDRC, Ottawa, Ontario, Canada.

Corraze, G. 1999. Nutrition lipidique. Pages 147-169 in J. Guillaume, S. Kaushik, P. Bergot, and R. Metailler, editors. Nutrition et alimentation des poissons et crustacés. Editions INRA-IFREMER, Saint Pee sur Nivelle, France.

Davenport, J., K. Black, G. Burnell, T. Cross, S. Culloty, S. Ekaratne, B. Furness, M. Mulcahy, and H. Thetmeyer. 2003. Aquaculture, the ecological issues. Blackwell Publishing, Oxford, UK.

De la Higuera, M., M. G. Garcia-Gallego, A. Sanz, G. Cardenote, M. D. Suarez, and F. J. Moyano. 1988. Evaluation of lupine seed meal as an alternative protein source in feeding of rainbow trout (Salmo gairdneri). Aquaculture 71:37-50.

Fagbenro, O. A. 1998. Apparent digestibility of various legume seed meals in Nile tilapia diets. Aquaculture International 6:83-87

FAO. 2008. State of world fisheries and aquaculture. FAO Fisheries and Aquaculture Department, Food and Agriculture Organization of the United Nations, Rome, Italy.

Farhangi, M. and C. G. Carter. 2001. Growth, physiological and immunological responses of rainbow trout (Oncorhynchus mykiss) to different dietary inclusion levels of dehulled lupine (Lupinus angustifolius). Aquaculture Research 32:329-340.

Folch, J., H. Less, and G. H. Sloane-Stanley. 1957. A simple method for the isolation and purification of total lipids from animal tissue. Journal of Biological Chemistry 226:497-509.

Furukawa, H. and H. Tsukahara. 1966. On the acid digestion method for the determination of chromic oxide as an index substance in the study of digestibility of fish feed. Bulletin of the Japanese Society of Scientific Fisheries 32(6):502-508.

Glencross, B. D. 2005. Proceedings of the Third Workshop for Seeding a Future for Grains in Aquaculture Feeds, 14 April 2005. Fisheries Occasional Publications. Department of Fisheries, Western Australia.

Glencross, B. D. 2007. Harvesting the benefits of grain in aquaculture feeds. Proceedings of a Workshop, 13 February 2007. Fisheries Occasional Publications No. 41. Department of Fisheries, Western Australia.
Glencross, B. D., J. Curnow, W. E. Hawkins, and M. Felsing. 2002. Evaluation of yellow lupine Lupinus luteus meal as an alternative protein resource in diets for sea-cage reared rainbow trout Oncorhynchus mykiss. Journal of World Aquaculture Society 33: 287-296.

Glencross, B. D., J. Curnow, W. E. Hawkins, G. W. Kissil, and D. Peterson. 2003. Evaluation of the feed value of a transgenic strain of the narrow-leaf lupine (Lupinus angustifolius) in the diet of the marine fish, Pagrus auratus. Aquaculture Nutrition 9:197-206.

Glencross, B. D., C. G. Carter, N. Duijster, D. R. Evans, K. Dods, P. McCafferty, W. E. Hawkins, R. Maas, and S. Sipsas. 2004. A comparison of the digestibility of a range of lupine and soybean protein products when fed to either Atlantic salmon (Salmo salar) or rainbow trout (Oncorhynchus mykiss). Aquaculture 237:333-346.

Gomes, E. F., G. Corraze, and S. Kaushik. 1993. Effects of dietary incorporation of a co-extruded plant protein (rapeseed and peas) on growth, nutrient utilization and muscle fatty acid composition of rainbow trout (Oncorhynchus mykiss). Aquaculture 113:339-353.

Gouveia, A., A. Oliva Teles, E. Gomes, and P. Rema. 1993. Effect of cooking/expansion of three legume seeds on growth and food utilization by rainbow trout. Pages 933-938 in S. J. Kaushik and P. Luquet, editors. Fish nutrition in practice. Les Colloques, no 61. INRA, Paris, France.

Guillaume, J. and Metailler, R. 1999. Mateares premières et additifs utilisés dans l'alimentation des poissons. Pages 147-169 in J. Guillaume, S. Kaushik, P. Bergot, and R. Metailler, editors. Nutrition et alimentation des poissons et crustacés. INRA-IFREMER, Paris, France.

Guillou, A., P. Soucy, M. Khalil, and L. Adambounou. 1995. Effects of dietary vegetable and marine lipid on growth, muscle fatty acid composition and organoleptic quality of flesh of brook charr (Salvelinus fontinalis). Aquaculture 136:351-362.

Hardy, R. and F. T. Barrows. 2002. Diet preparation and manufacture. Pages 506-601 in J. Halver and R. Hardy, editors. Fish nutrition. Academic Press Inc., London, UK.

Hasan, M. R. 2001. Nutrition and feeding for sustainable aquaculture development in the third millennium. Pages 193-219 in R. P. Subasinghe, P. Bueno, M. J. Phillips, C. Hough, S. E. McGladdery, and J. R. Arthur, editors. Aquaculture in the third Millennium. Technical Proceedings of the Conference on Aquaculture in the Third Millennium, Bangkok, Thailand, 20-25 February 2000. FAO, Rome, Italy.

Henderson, R. 1996. Fatty acid metabolism in freshwater fish with particular reference to polyunsaturated fatty acids. Archives of Animal Nutrition 49:5-22.

Hernández, A., S. Satoh, V. Kiron, and T. Watanabe. 2004. Phosphorus retention efficiency in rainbow trout fed diets with low fish meal and alternative protein ingredients. Fisheries Science 70:580-586. 
Hughes, S. G. 1988. Assessment of lupine flour as a diet ingredient for rainbow trout (Salmo gairdneri). Aquaculture 71:379-385.

Hughes, S. G. 1991. Use of lupine flour as a replacement for full-fat soy in diets for rainbow trout (Oncorhynchus mykiss). Aquaculture 93:57-62.

Luzier, J. M., R. C. Summerfelt, and H. G. Ketola. 1995. Partial replacement of fish meal with spray-dried blood powder to reduce phosphorus concentrations in diets for juvenile rainbow trout, Oncorhynchus mykiss (Walbaum). Aquaculture Research 26:577-587.

Masson, L. and M. Mella. 1985. Materias grasas de consumo habitual y potencial en Chile. Editorial Universitaria Monografía. Santiago de Chile, Chile.

Montero, D., L. E. Robaina, J. Socorro, J. M. Vergara, L. Mort, and M. S. Izquierdo. 2001. Alteration of liver and muscle fatty acid composition in gilthead seabream (Sparus aurata) juveniles held at high stocking density and fed an essential fatty acid deficient diet. Fish Physiology Biochemistry 24:63-72.

Morales, A. E., G. Cardenete, M. De la Higuera, and A. Sanz. 1994. Effects of dietary protein source on growth, feed conversion and energy utilization in rainbow trout, Oncorhynchus mykiss. Aquaculture 124:117-126.

Morrison, W. R. and L. Smith. 1964. Separation of fatty acid methyl esters and dimethyl-acetols from lipids with boron fluoride-methanol. Journal of Lipid Research 5:600-608.

Petterson, D. 2000. The use of lupin in feeding system.Review: Asian Australian Journal of Animal Science. 13(6):861-882.

Petterson, D. S., S. Sipsa, and J. B. Mackintosh. 1997. The chemical composition and nutritive value of Australian pulses. Grains Research and Development Corporation, Canberra, Australia.

Pongmaneerat, J., T. Watanabe, T. Takeuchi, and S. Satoh. 1993. Use of different protein meals as partial or total substitution for fish meal in carp diets. Nippon Suisan Gakkaishi 59:1249-1257.

Riche, M. and P. B. Brown. 1999. Incorporation of plant protein feedstuffs into fish meal diets for rainbow trout increases phosphorus availability. Aquaculture Nutrition 5:101-105.

Robaina, L., M. Izquierdo, F. Moyano, J. Socorro, J. Vergara, D. Montero, and H. Fernandez. 1995. Soybean and lupin seed meals as meals as protein sources in diets for gilthead seabream (Sparus aurata): nutritional and histological implications. Aquaculture 130:219-233.

Russell, P., S. Davies, A. Gouveia, and A. Tekinay. 2001. Influence of dietary starch source on liver morphology in juvenile cultured European sea bass (Dicentrarchus labrax L.). Aquaculture Research 32:306-314.

Satoh, S., A. Hernández, T. Tokoro, Y. Morishita, V. Kiron, and T. Watanabe. 2003. Comparison of phosphorus retention efficiency between rainbow trout (Oncorhynchus mykiss) fed a commercial diet and a low fish meal based diet. Aquaculture 224:271-282.

Shearer, K. 1994. Factors affecting the proximate composition of cultured fishes with emphasis on salmonids. Aquaculture 119:63-88.

Sheridan, M. A., W. V. Allen, and T. H. Kerstetter. 1985. Changes in the fatty acid composition of steelhead trout, Salmo gairdnerii Richardson, associated with parr-smolt transformation. Comparative Biochemistry and Physiology 80B:671-676.

Storebakken, T., K. D. Shearer, and A. J. Roem. 2000a. Growth, uptake and retention of nitrogen and phosphorus, and absorption of other minerals in Atlantic salmon Salmo salar fed diets with fish meal and soyprotein concentrate as the main sources of protein. Aquaculture Nutrition 6:103-108.

Storebakken, T., S. Refstie, and B. Ruyter. 2000b. Soy products as fat and protein sources in fish feeds for intensive aquaculture. Pages 127-170 in J. K. Drackley, editor. Soy in animal nutrition. Federation of Animal Science Societies, Savoy, Illinois, USA.

Tacon, A. 1994. Feed ingredients for carnivorous fish species alternatives to fishmeal and other fishery resources. FAO fisheries circular. FAO, Rome, Italy.

Tacon, A. 1997. Fishmeal replacers: review of antinutrients within oilseeds and pulses, a limiting factor for aquafeed green revolution? Pages 153-182 in A. Tacon and B. Basurco, editors. Feeding tomorrow's fish. Editions Cahiers Options Mediterranéennes, volume 22. CIHEAM, Zaragoza, Spain.

Tacon, A. G. J. and S. F. Nates. 2007. Meeting the feed supplies challenges. Pages 117-124 in R. Arthur and J. Nierentz, editors. Global Trade Conference on Aquaculture, Qingdao, China, 29-31 May 2007. FAO Fisheries Proceedings No. 9. FAO, Rome, Itlay.

Torstensen, B. E., O. Lie, and L. Froylond. 2000. Lipid metabolism and tissue composition in Atlantic salmon (Salmo salar): effects of capelin oil, palm oil, and oleic acid enriched sunflower oil as dietary lipid sources. Lipids 32:653-664.

Viyakarn, V., T. Watanabe, H. Aoki, H. Tsuda, H. Sakamoto, N. Okamoto, N. Iso, S. Satoh, and T. Takeuchi. 1992. Use of soybean meal as a substitute for fishmeal in a newly developed softdry pellet for yellowtail. Nippon Suisan Gakkaishi 58:1991-2000.

Watanabe, T. 1982. Lipid nutrition in fish. Comparative Biochemistry and Physiology 73B:3-15.

Watanabe, T., J. Pongmaneerat, S. Satoh, and T. Takeuchi. 1993. Replacement of fish meal by alternative protein sources in rainbow trout diets. Nippon Suisan Gakkaishi 59:1573-1579.

Watanabe, T., V. Verakunpiriya, K. Watanabe, V. Kiron, and S. Satoh. 1997. Feeding of rainbow trout with non-fish meal diets. Fisheries Science 63:258-266.

Watanabe, T., H. Aoki, K. Shimamoto, M. Hadzuda, M. Maita, Y. Yamagata, V. Kiron, and S. Satoh. 
1998. A trial to culture yellowtail with non-fishmeal diets. Fisheries Science 64:505-512.

Wurmann, C. 2007. Salmon farming in Chile: history, policies and development strategies. Pages 415-444 in P. S. Leung, C. S. Lee, and P. J. O’Bryen, editors.
Species and system selection for sustainable aquaculture. Blackwell Publishing, Oxford, UK.

Yañez, E., D. Ivanovic, D. Owen, and D. Ballester. 1983. Chemical and nutritional evaluation of sweet lupines. Annals of Nutrition and Metabolism 27:513-520. 